\title{
Rancang Bangun Aplikasi Terapi Pascastroke untuk Latihan Pergerakan Jari Tangan dengan Menggunakan Leap Motion Controller
}

\author{
Franky Setiawan Daldiri, Wijayanti Nurul Khotimah, dan Darlis Herumurti \\ Departemen Teknik Informatika, Fakultas Teknologi Informasi, Institut Teknologi Sepuluh Nopember (ITS) \\ e-mail: wijayanti@if.its.ac.id, darlis@if.its.ac.id, setiawan.franky13@mhs.if.its.ac.id
}

\begin{abstract}
Abstrak-Teknologi dengan memanfaatkan motion capture sangat berkembang pesat seperti Leap Motion Controller yang merupakan alat yang berfungsi sebagai alternatif kontrol input dalam interaksi antara manusia dengan komputer tanpa menggunakan sentuhan dengan hasil yang lebih halus serta detail. Ide yang digunakan dalam studi ini yaitu membangun sebuah aplikasi terapi untuk pengguna pascastroke khususnya pada anggota gerak tangan. Aplikasi ini dibangun menggunakan Unity dengan Leap Motion SDK. Dengan studi ini diharapkan pengguna dapat melakukan terapi secara berkesinambungan dengan tidak bosan. Aplikasi telah diuji oleh seorang pasien pascastroke. Hasil dari uji coba berupa data waktu lama pasien pascastroke melakukan terapi pada tiap tahap, kemudian dari data ini dapat ditarik kesimpulan perkembangan pasien serta aplikasi ini dapat menciptakan pelatihan untuk terapi gerak tangan. Sehingga secara tidak langsung aplikasi ini dapat memberikan motivasi kepada pasien untuk terus melakukan terapi.
\end{abstract}

Kata Kunci_Leap Motion Controller, Pascastroke, Unity.

\section{PENDAHULUAN}

$\mathrm{P}$ ERKEMBANGAN teknologi komputer khususnya di bidang Interaksi Manusia dan Komputer (IMK) merupakan perkembangan teknologi yang menjadi pusat perhatian sejak munculnya perangkat baru yang memanfaatkan motion capture untuk menunjang interaksi dengan komputer (seperti Nintendo Wii Remote, Kinect dan Leap Motion) [1]. Penggunaan antarmuka dengan memanfaatkan gerakan dapat meningkatkan keuntungan dan kemudahan, terlebih lagi interaksi merupakan bagian penting dalam aplikasi seperti seni, bantuan medis, dan simulasi.

Stroke atau cerebrovascular accident (CVA), adalah hilangnya fungsi-fungsi otak dengan cepat, karena gangguan suplai darah ke otak. Stroke dapat berdampak pada kehidupan penderitanya seperti menggerakkan anggota tubuh, bahkan depresi yang berat. Sebelum pulih seutuhnya penderita perlu melakukan terapi secara simultan dan dalam waktu yang panjang. Namun sebagian besar dari mereka tidak melakukan terapi secara terus menerus dikarenakan biaya terapi yang relatif mahal dan memerlukan waktu yang lama untuk melakukan terapi secara konvensional seperti perlunya mengantri terlebih dahulu.

Berbagai macam inovasi telah terealisasi mulai dari deteksi dini gejala stroke, sampai terapi pascastroke. Aplikasi terapi pascastroke terdahulu yaitu menggunakan teknologi augmented reality (AR), konsol wii dan kinect. Akan tetapi aplikasi terdahulu memiliki beberapa kelemahan seperti pada teknologi AR dimana tangan virtual sering kali hilang, pada konsol wii pasien harus menggunakan remote, pada teknologi yang memanfaatkan kinect anggota gerak tangan pasien kurang dilatih dengan gerakan yang bermacam-macam.

Maka dari itu, penulis membuat aplikasi terapi pascastroke khusus bagian anggota gerak tangan dengan memanfaatkan teknologi Leap Motion Controller (LMC) yang memiliki keakuratan tangkapan gerak tangan yang lebih baik dari AR serta dapat memiliki bermacam-macam gerakan terapi khusus untuk tangan.

\section{TINJAUAN PUSTAKA}

\section{A. Stroke}

Stroke adalah suatu kejadian rusaknya sebagian dari otak. Terjadi jika pembuluh darah arteri yang mengalirkan darah ke otak tersumbat atau jika robek atau bocor, stroke dibagi menjadi dua jenis yaitu stroke iskemik maupun stroke hemorragik [2]. Jika terlambat penanganannya, maka pasien akan menderita pascastroke yang lebih berat.

\section{B. Terapi Fisik Anggota Gerak Tangan Pascastroke}

Terapi fisik anggota gerak tangan pascastroke merupakan suatu upaya yang dapat ditempuh melalui berbagai cara seperti pelatihan, penggunaan modalitas, dan alat-alat. Latihan terapi anggota gerak tangan terdapat beberapa pengelompokan gerak seperti upper arm function, hand movement, dan advance hand activities [3]. Semua pengelompokan tersebut disusun dan dikelompokkan untuk mendapatkan gerakan yang dapat dijadikan sebagai referensi untuk rancangan tahapan terapi, beberapa gerakan tersebut seperti:

1. Gerakkan kaki dari sisi kanan ke kiri dan sebaliknya [4]

2. Gerakkan kaki untuk mendapatkan objek yang dicari [4]

3. Gerakan mengangkat tangan [5] [3]

4. Gerakan menurunkan tangan [5] [3]

5. Gerakan menekuk dan meluruskan sendi bahu [5]

6. Gerakan menekuk dan meluruskan siku [5]

7. Gerakan menekuk dan meluruskan telapak tangan [5]

8. Gerakan memutar pergelangan tangan [5] [6]

9. Gerakan menggenggam dan melepas [6] [3]

10. Menggambar garis horizontal [3] 


\section{Fisioterapi}

Fisioterapi adalah bentuk pelayanan kesehatan professional yang ditujukan kepada individu dan kelompok untuk mengembangkan, memelihara dan memulihkan gerak serta fungsi tubuh sepanjang daur kehidupan dengan menggunakan penanganan secara manual, peralatan ( fisik dan mekanik) dan komunikasi [7].

\section{Unity $3 D$}

Unity3D adalah software yang baik yang merupakan crossplatform 3D dan user-friendly, mudah bagi pemula dan sangat berguna untuk para ahli. Aplikasi ini sangat. Membantu bagi siapa saja yang akan membangun sebuah game baik itu dekstop, mobile, website ataupun konsol [8]. Unity memiliki banyak sekali kegunaan seperti dapat merangkai objek-objek menjadi sebuah lingkungan yang dapat berinteraksi, menambahkan pencahayaan, suara, efek, dan animasi.

\section{E. Leap Motion}

Leap Motion merupakan alat sensor gerakan jari tangan dan tangan sebagai masukan. Leap Motion sendiri memiliki hardware yang cukup sederhana. Hal utama yang terdapat pada Leap Motion yaitu 2 buah kamera dan 3 buah inframerah LED (Light-Emitting Diode) [9]. Inframerah akan menyebar untuk membentuk sebuah area seperti setengah lingkaran dengan jarak jangkauan maksimal $50 \mathrm{~cm}$ yang berguna sebagai area tangkapan gerakan.

\section{F. Blender}

Blender adalah sebuah perangkat lunak yang berfungsi untuk pemodelan 3 dimensi dan bersifat open source. Blender dapat digunakan pada berbagai jenis sistem operasi. Keluaran dari Blender adalah objek-objek 3 dimensi dengan berbagai format, seperti .obj, .3ds, dan lain-lain [10]. Objek keluaran dari Blender dapat digunakan sebagai material dasar pembuatan aplikasi atau permainan dengan menggunakan game engine atau perangkat lunak pembuat aplikasi 3 dimensi.

\section{G. Teknologi Informasi untuk Terapi Rehabilitasi Penderita Pascastroke}

Teknologi informasi yang berkembang pesat memungkinkan dapat membantu pada bidang kedokteran, salah satu contoh yaitu terapi pascastroke. Terapi pascastroke terdahulu yang telah menggunakan teknologi informasi sebagai media terapi yang dikemas dalam sebuah game yang menarik yaitu memanfaatkan teknologi seperti kinect, augmented reality, dan konsol wii.

\section{ANALISIS DAN PERANCANGAN}

\section{A. Analisis Perangkat Lunak}

Aplikasi terapi untuk pengguna pascastroke ini bertujuan bagi pengguna pascastroke yang tidak mengalami kelumpuhan tangan total tetapi pengguna yang masih memiliki keterbatasan gerak serta memiliki kekuatan dalam menggerakan tangan secara mandiri. Aplikasi ini memanfaatkan fitur yang dimiliki oleh LMC yaitu tools and finger detection, fitur ini memungkinkan pengguna untuk berinteraksi dengan aplikasi tanpa menyentuhnya. Interaksi antar pengguna dengan

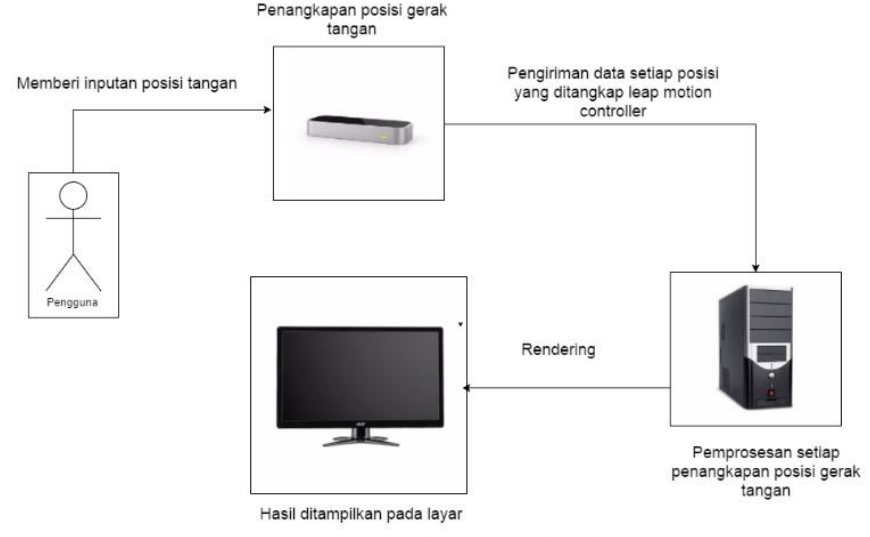

Gambar 1. Rancangan Sederhana Arsitektur Aplikasi

objek 3D dilakukan dengan inputan berupa gerakan tangan dari pengguna, dari inputan aplikasi akan melakukuan rendering menjadi sebuah tangan virtual pada monitor. Hasil berupa lama waktu terapi akan disimpan dalam bentuk teks yang kemudian dapat dijadikan acuan perkembangan. Adapun gambaran arsitektur secara umum aplikasi dapat dilihat pada Gambar 1.

\section{B. Perancangan Perangkat Lunak}

Pada perancangan perangkat lunak menjelaskan perancangan proses beserta alurnya. Pada aplikasi memiliki rancangan proses yang dilakukan untuk mendukung fungsionalitas yang sudah dirancang pada aplikasi dimulai dari proses penentuan tahap hingga proses permainan terapi.

\section{1) Proses penentuan tahapan terapi}

Rancangan gerakan pada setiap tahap pelatihan terinspirasi dari gerakan terapi stroke di dalam dunia kedokteran pada II.B Terapi Fisik Anggota Gerak Tangan Pascastroke dan untuk susuanan tahap yang dihasilkan didasari dari pertimbangan kompleksitas gerakan yang dihasilkan, macam tahapan dalam aplikasi yaitu:

Tahap 1:

1. Gerakan mengangkat tangan

2. Gerakan menurunkan tangan

3. Gerakan menggerakkan tangan ke depan

4. Gerakan menggeser tangan

5. Memutar pergelangan tangan

Tahap 2:

1. Kombinasi semua gerakan tahap pertama

Tahap 3:

1. Gerakan mengambil benda

Tahap 4:

1. Gerakan kestabilan dengan mengambar garis lurus

2. Gerakan kestabilan dengan menggambar segitiga

3. Gerakan kestabilan dengan menggambar persegi

\section{2) Proses Permainan}

Pengguna dianjurkan untuk memilih menu "Pelajari Selengkapnya" karena pada menu ini akan di tampilkan penjelasan singkat tiap tahap. Pada setiap tahap terapi tidak ada batasan waktu sehingga pengguna dapat terus mencoba hingga berhasil karena waktu yang dibutuhkan oleh pengguna dalam menyelesaikan setiap tahapan merupakan data yang akan 
dinilai. Alur proses permainan digambarkan pada Gambar 2.

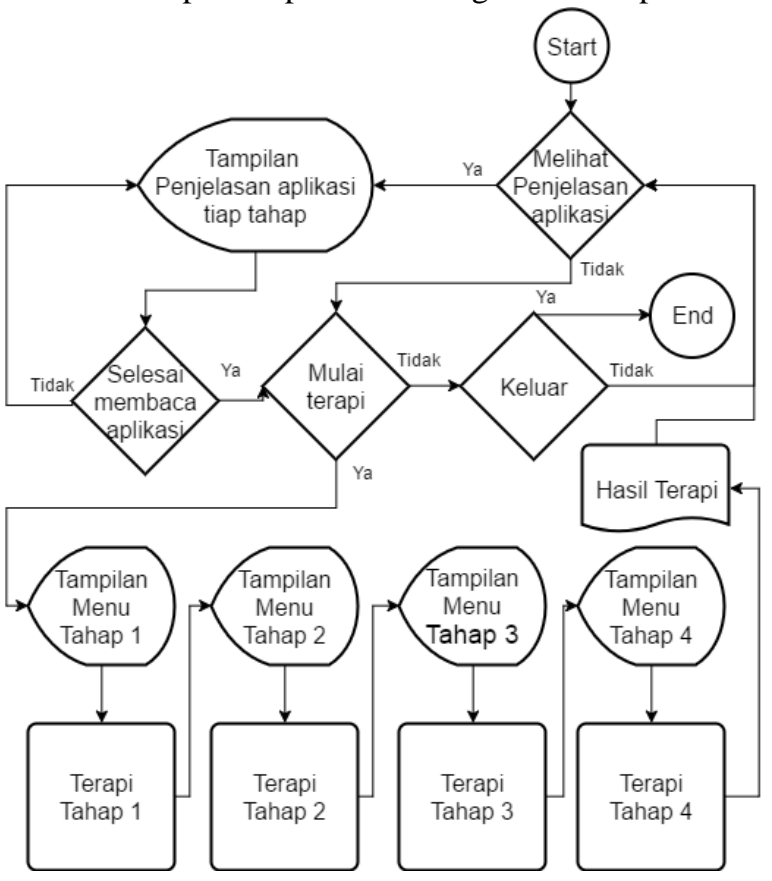

Gambar 2. Alur Proses Permainan

Ketika pengguna berada pada menu utama dan memilih tombol mulai maka pengguna akan dihadapkan pada penjelasan menu tahap 1 dan jika selesai maka pengguna menekan tombol "mulai" untuk memulai melakukan terapi tahap 1. Ketika aplikasi berada pada tahap 1 maka secara bersamaan waktu pun berjalan dan dicatat hingga pengguna menyelesaikannya maka waktu disimpan secara sementara pada game. Kemudian pengguna akan melanjutkan ke tahap 2, tahap 3, dan tahap 4, jika sampai tahap 4 selesai maka semua waktu pada tiap-tiap tahap akan di export dalam bentuk teks yang berada pada folder aplikasi tersebut serta aplikasi akan kembali ke menu utama.

\section{IMPLEMENTASI}

Pada implementasi, aplikasi dibangun menggunakan bahasa pemrograman C\#, perangkat pengembang Unity 3D, Blender, serta Library Leap Motion SDK. Jika terdapat gerakan tangan pada area LMC maka controller mulai untuk mendeteksi setiap gerakan tangan tersebut untuk menjadikan inputan seperti Gambar 3. Ketika suatu waktu pengguna melakukan gerakan menggenggam maka proses pelacakan "menggenggam" diimplementasikan dalam kelas MagneticPinch dalam kelas ini terdapat dua fungsi utama yaitu OnPinch dan OnRelease sehingga aplikasi akan mengenali bila pengguna melakukan genggaman atau melakukan melepas genggaman sehingga pengguna dapat mengambil benda yang terdekat dengan tangan virtual seperti pada Gambar 4.

Pada permainan aplikasi ini, pengguna memilih tombol "Mulai" pada aplikasi, maka pengguna memasuki tahap 1. Terapi akan dimulai dari tahap pertama hingga terakhir secara beruntun dimulai dari gerakan dasar hingga yang membutuhkan keakuratan yang tinggi. Halaman terapi memiliki informasi waktu yang ditampilkan pada bagian atas sebelah kanan sehingga pengguna dapat melihat lama waktu selama memainkan tahap tersebut dan memiliki instruksi gambar yang bergerak pada objek yang ditargetkan serta memiliki instruksi berupa teks yang berada pada sebelah kiri layar, instruksi teks tampil ketika pengguna memasuki level baru dan akan hilang dengan sendirinya selama beberapa selang waktu. Halaman terapi dapat dilihat pada Gambar 5.

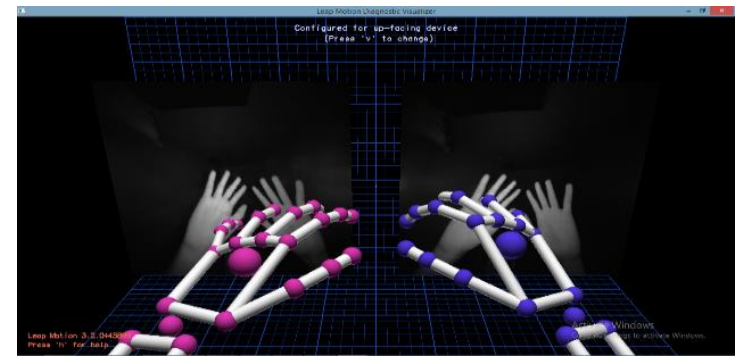

Gambar 3. Deteksi Tangan Oleh LMC

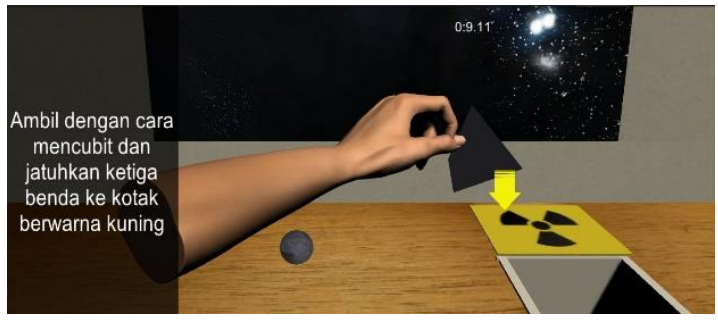

Gambar 4. Pengguna Ketika Menggenggam

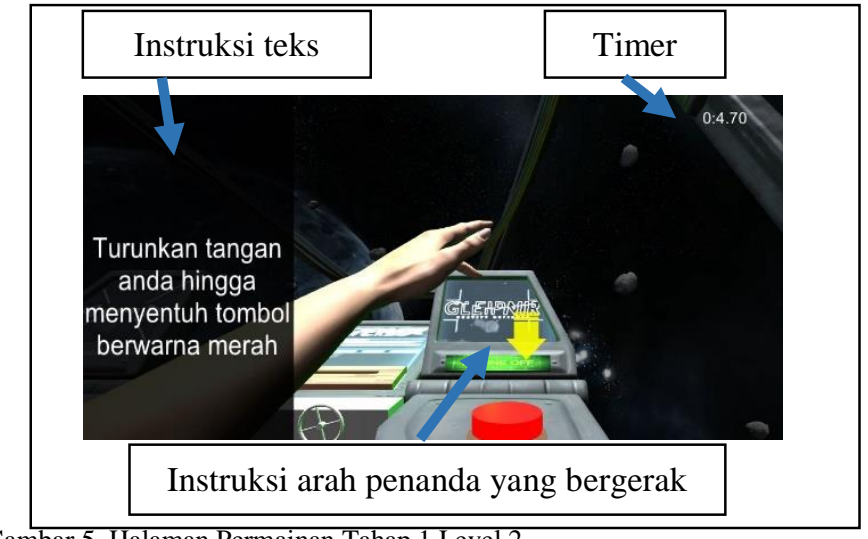

Gambar 5. Halaman Permainan Tahap 1 Level 2

\section{PENGUJIAN TERHADAP PENGGUNA}

Setelah aplikasi selesai dalam proses pengembangan, maka aplikasi perlu dilakukan pengujian fungsionalitas. Uji fungsionalitas akan dilakukan oleh penulis, apabila aplikasi telah memenuhi semua fungsionalitas maka pengujian aplikasi akan dilanjutkan dengan pengujian oleh pengguna pascastroke. Pengujian melibatkan dua orang yaitu seorang pengguna pascastroke (Pengguna A) dan pengguna dengan kondisi kesehatan normal sebagai pendamping (Pengguna B). Metode kuesioner yang digunakan adalah Likert-type scale dengan skala 1-6. Pengguna A diminta untuk memainkan aplikasi ini, setelah itu pengguna B diminta untuk mengisi kuesioner. Bobot penilaian sebagai berikut:

1. sangat tidak setuju $=1$,

2. tidak setuju $=2$,

3. kurang setuju $=3$, 

4. cukup setuju
$=4$,
5. setuju
$=5$,
6. sangat setuju
$=6$.

Hasil kuesioner terhadap pengguna dapat dilihat pada Tabel 1. Tabel 1.

Hasil Kuesioner

\begin{tabular}{|c|c|c|c|}
\hline No & Parameter Antarmuka & Target & $\begin{array}{c}\text { Nilai (1- } \\
\text { 6) }\end{array}$ \\
\hline 1 & $\begin{array}{l}\text { Aplikasi memiliki tampilan, warna dan } \\
\text { desain yang menarik }\end{array}$ & $\begin{array}{l}\text { Penggun } \\
\mathrm{a}\end{array}$ & 4 \\
\hline 2 & $\begin{array}{l}\text { Aplikasi mudah dipahami dan } \\
\text { dioperasikan }\end{array}$ & Admin & 5 \\
\hline 3 & $\begin{array}{l}\text { Aplikasi memiliki objek permainan yang } \\
\text { menarik }\end{array}$ & $\begin{array}{l}\text { Penggun } \\
\mathrm{a}\end{array}$ & 5 \\
\hline No & Parameter Kenyamanan & Target & $\begin{array}{l}\text { Nilai } \\
(1-6)\end{array}$ \\
\hline 4 & $\begin{array}{l}\text { Aplikasi dapat berjalan lancar tanpa } \\
\text { adanya lag dan crash }\end{array}$ & $\begin{array}{l}\text { Penggun } \\
\text { a }\end{array}$ & 4 \\
\hline 5 & $\begin{array}{l}\text { Saya merasa terbantu dengan adanya } \\
\text { tutorial yang disediakan }\end{array}$ & Admin & 5 \\
\hline 6 & $\begin{array}{l}\text { Saya merasa tertarik untuk menggunakan } \\
\text { aplikasi ini }\end{array}$ & $\begin{array}{l}\text { Penggun } \\
\text { a }\end{array}$ & 5 \\
\hline No & Parameter Kegunaan & Target & $\begin{array}{l}\text { Nilai } \\
(1-6)\end{array}$ \\
\hline 7 & $\begin{array}{l}\text { Saya merasa terbantu dengan adanya } \\
\text { aplikasi ini sebagai salah satu media terapi }\end{array}$ & $\begin{array}{l}\text { Penggun } \\
\mathrm{a}\end{array}$ & 5 \\
\hline 8 & $\begin{array}{l}\text { Aplikasi dapat memberikan macam gerak } \\
\text { terapi yang tepat dan benar }\end{array}$ & $\begin{array}{l}\text { Penggun } \\
\mathrm{a}\end{array}$ & 5 \\
\hline
\end{tabular}

Dari desain antarmuka aplikasi sudah baik dan mudah dipahami serta memiliki objek-objek yang mudah untuk dikenali sehingga mendapat nilai rata-rata parameter sebesar 4,67 dan dalam persentase $77,77 \%$. Untuk tingkat kenyamanan aplikasi ini masih terdapat frame drop. Hal tersebut terjadi apabila komputer menjalankan beberapa aplikasi lain yang memberatkan proses komputer. Tetapi dari segi tutorial yang mudah serta jarangnya lag maka nilai rata-rata dapat mencapai 4,67 dan dalam persentase 77,77\%. Dari tingkat kegunaan aplikasi ini cukup berguna bagi pasien pasca stroke, akan tetapi masih perlu penambahan gerak dalam terapi. Nilai rata-rata mencapai 5 dan dalam persentase sebesar 83,33\%.

Pengujian terakhir aplikasi yaitu mengadakan konsultasi dengan ahli fisioterapi. Terapis tersebut memberikan saran untuk pengembangan selanjutnya memerlukan tambahan gerakan yang melibatkan aktivitas sehari-hari seperti makan, mandi, merapikan rambut, dan menggosok gigi.

\section{KESIMPULAN/RINGKASAN}

Aplikasi terapi virtual untuk pengguna pascastroke yang dibangun berhasil menciptakan sebuah media baru untuk melakukan latihan terapi pascastroke khusus pada organ gerak tangan. Dari hasil pengujian, dapat diambil kesimpulan bahwa aplikasi ini dapat membantu pasien pascastroke dalam melakukan terapi secara virtual walaupun perkembangan dari pengguna tersebut belum dapat ditentukan karena masih membutuhkan banyak data yang diperoleh dari pengguna dan aplikasi memerlukan tambahan macam gerakan fungsional seperti dalam kehidupan sehari-hari.

\section{UCAPAN TERIMA KASIH}

Penulis F.S.D. mengucapkan terima kasih kepada Jurusan
Teknik Informatika Institut Teknologi Sepuluh Nopember, Direktorat Pendidikan Tinggi, Departemen Pendidikan dan Kebudayaan Republik Indonesia yang telah memfasilitasi penelitian ini.

\section{DAFTAR PUSTAKA}

[1] V. T. and G. L. R. E. S. Silva, J. A. O. d. Abreu, J. H. P. d. Almeida, "A Preliminary Evaluation of the Leap Motion Sensor as Controller of New Digital Musical Instruments," $14^{o}$ Simpósio Bras. Comput. Bras. Soc. Bras. Comput. - SBC, pp. 59-70, 2013.

[2] Wikipedia, "Stroke," Wikipedia, 2016. [Online]. Available: https://id.wikipedia.org/w/index.php?title=Stroke\&oldid=12066095. R.S.J.Carr, Motor Assessment Scale for Stroke, 2nd. 1994.

[4] W. K. and R. W.Sholikah, "Sitting To Standing and Walking Theraphy for Post-Stroke Patients using Virtual Reality System," 2015.

[5] MahendralkkhuGincung, "bahan_SAP_senaam_stroke," 2017. [Online]. Available: https://www.scribd.com/document/349210268/bahan-SAP-senaamstroke-1-docx.

[6] I. F. and N. Amalia, Mengantisipasi stroke petunjuk mudah lengkap dan praktis sehari hari. Yogyakarta: Buku Biru, 2009.

[7] R. S. JIH, "Fisioteraphy | Rumah Sakit JIH," 2016. [Online]. Available: https://www.rs-jih.co.id/layanan/fisioteraphy.

C. E. Tuts+, "Introduction to Unity 3D," 2016. [Online]. Available: https://code.tutsplus.com/tutorials/introduction-to-unity3d--mobile10752.

[9] L. Motion, "Leap Motion,” 2016. [Online]. Available: https://www.leapmotion.com/product/desktop.

[10] Blender, "about-blender," 2014. [Online]. Available: http://www.blender.org/about/. 